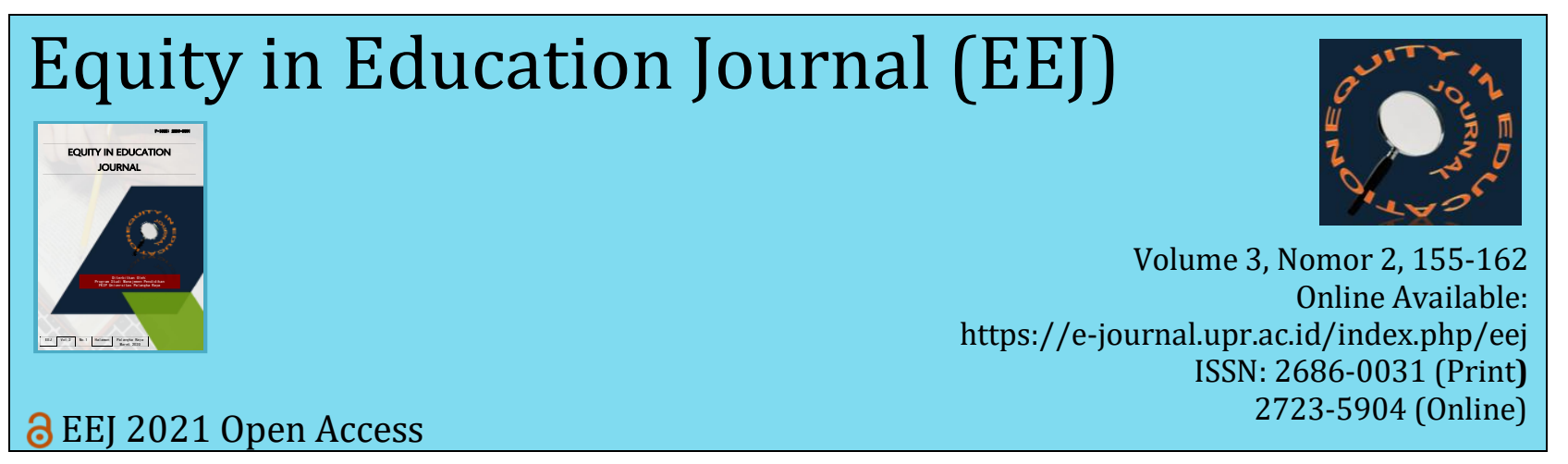

\title{
MANAJEMEN SISTEM NASKAH DINAS ELEKTRONIK (SINDE) PADA LEMBAGA PENJAMINAN MUTU PENDIDIKAN PROVINSI KALIMANTAN TENGAH
}

\author{
Winda Sinta Dewi*, Slamet Winaryo, Sumarnie \\ Universitas Palangka Raya, Palangka Raya
}

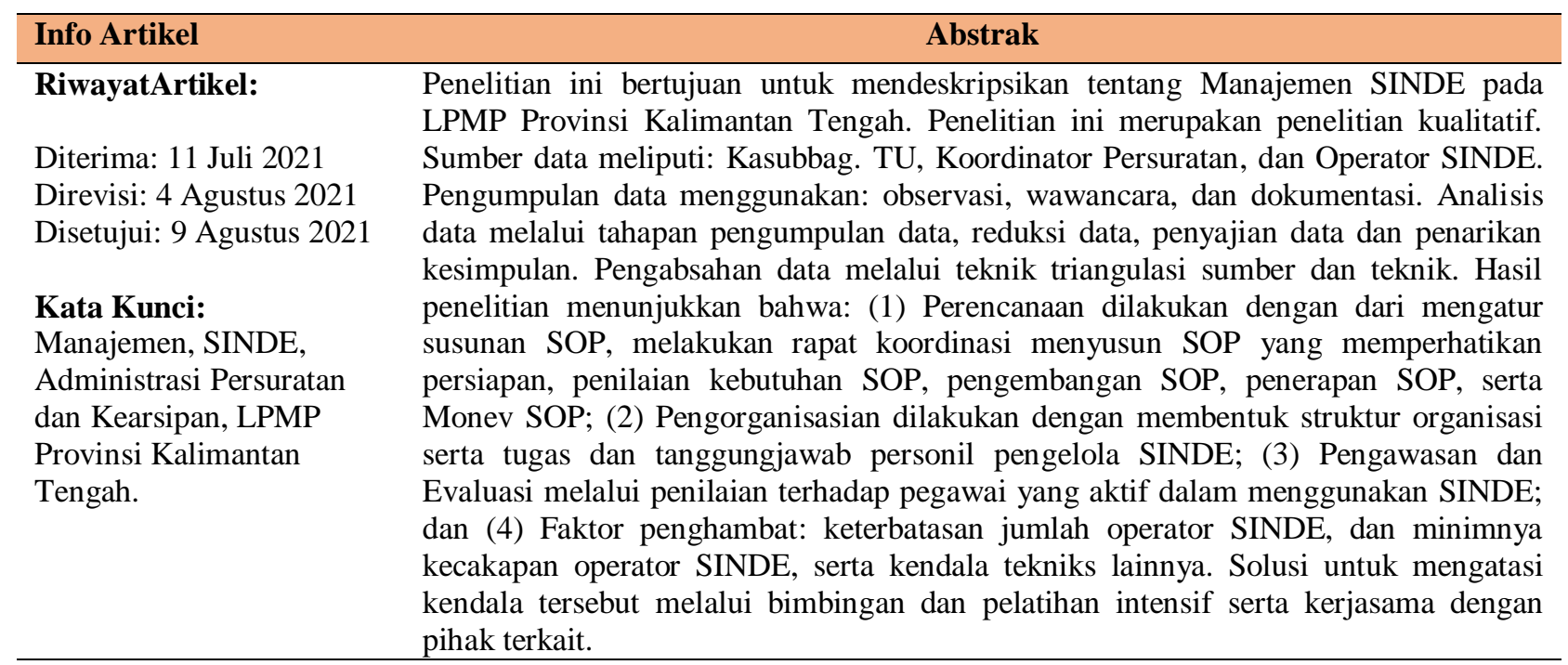

Korespondensi:

Winda Sinta Dewi*

Universitas Palangka Raya

Email:

windasdewi27@gmail.com
This study aims to describe the SINDE Management at LPMP Central Kalimantan Province. This research is a qualitative research. Sources of data include: Head of Subsection. TU, Mailing Coordinator, and SINDE Operator. Collecting data using: observation, interviews, and documentation. Data analysis through the stages of data collection, data reduction, data presentation and drawing conclusions. Validation of data through source and technique triangulation techniques. The results of the study indicate that: (1) Planning is carried out by arranging the composition of SOP, conducting coordination meetings to prepare SOPs that pay attention to preparation, assessment of SOP needs, SOP development, SOP implementation, and SOP Monev; (2) Organizing is done by establishing an organizational structure as well as the duties and responsibilities of SINDE management personnel; (3) Supervision and Evaluation through assessment of employees who are active in using SINDE; and (4) inhibiting factors: the limited number of SINDE operators, and the lack of skills of SINDE operators, as well as other technical obstacles. The solution to overcome these obstacles is through intensive guidance and training as well as collaboration with related parties.

\section{PENDAHULUAN}

Tata naskah dinas dapat diartikan dengan tata persuratan dinas. Dalam pelaksanaanya digunakan untuk mengatur proses kegiatan surat menyurat, meliputi: surat masuk, surat keluar, dan pengarsipan. Tata persuratan berperan penting dalam lembaga/instansi karena persuratan 
merupakan media komunikasi untuk memperoleh berbagai informasi. Dalam Permendikbud Nomor 74 Tahun 2015 tentang Tata Naskah Dinas di Lingkungan Kementerian Pendidikan dan Kebudayaan menjelaskan bahwa tata naskah adalah pengelolaan informasi tertulis yang meliputi pengaturan jenis, format, penyiapan, pengamanan, pengesahan, distribusi, dan penyimpanan naskah dinas, serta media yang digunakan dalam kedinasan. Dapat dipahami bahwa tata naskah dinas adalah proses pengelolaan persuratan dari menginput surat, memproses surat, hingga mendistribusikan surat dan peyimpanan surat.

Proses persuratan di berbagai lembaga maupun instansi secara umum masih banyak menggunakan sistem manual, dimana pengelolaan persuratan masih dilakukan pengetikan melalui microsoft word. Hal tersebut belum cukup memadai dengan keperluan persuratan yang makin tinggi dan menuntut kecepatan waktu. Disamping itu seiring berjalannya waktu perkembangan teknologi informasi terus meningkat pesat, menuntut adanya pemanfaatan teknologi dalam sistem naskah pemerintahan. Oleh sebab itu untuk menjalankan tugas pemerintahan dengan baik dan akuntabel, perlu dibuat sistem administrasi yang berguna mempercepat arus data dan informasi antara pemerintahan dengan yang bersangkutan. Menteri Negara Pendayagunaan Aparatur Negara dan Reformasi Birokrasi mengembangkan Tata Naskah Dinas Elektronik untuk menunjang pelaksanaan administrasi tata naskah dinas dengan pemanfaatan teknologi informasi semaksimal mungkin. Peraturan Menteri Pendayagunaan Aparatur Negara dan Reformasi Birokrasi (Permenpan-RB) Nomor 6 Tahun 2011 tentang Pedoman Umum Tata Naskah Dinas Elektronik (TNDE) pada bagian pengertian umum menyatakan: "Tata Naskah Dinas Elektronik adalah pengelolaan Nasakah Dinas secara elektronik dengan memanfaatkan teknologi informasi dan komunikasi untuk kecepatan dan kemudahan dalam proses pengambilan keputusan". Hal ini telah ditetapkan kebijakan pengelolaan tata naskah dinas secara elektronik melalui Permenpan-RB Nomor 6 Tahun 2011 tentang Pedoman Umum Tata Naskah Dinas Elektronik (TNDE). Pada tahun 2013, Menteri Pendayagunaan Aparatur Negara dan Refomasi Birokrasi mengeluarkan Surat Edaran Nomor 6 tentang Aplikasi Tata Naskah Dinas Elektronik pada Instansi Pemerintah. Tata naskah dinas elektronik ini dikembangkan pada setiap lembaga pemerintahan, sehingga terwujudnya keterpaduan dan kebersinambungan pengelolaan naskah dinas elektronik di lingkungan pusat, satuan kerja, dan unit pelaksanaan teknis di daerah.

Pengembangan sistem ini salah satu program reformasi birokrasi di lingkungan kementerian memudahkan dan membantu mendorong aparatur negara untuk terwujudnya sistem tata kelola pemerintahan yang baik. Pengembangan sistem naskah dinas elektronik dibuat agar pengelolaan naskah dinas berjalan efektif, efisien, terencana, dan akuntabel. Kementerian Pendidikan dan Kebudayaan (Kemendikbud) sadar dengan adanya kemajuan teknologi informasi saat ini bisa memudahkan dan membantu mendorong aparatur negara untuk terwujudnya sistem tata kelola pemerintahan yang baik salah satunya dengan sistem persuratan secara digital yang dikenal dengan Sistem Naskah Dinas Elektronik (SINDE).

SINDE merupakan sistem yang berbasis TIK. Sistem ini dibuat untuk membantu tatalaksana surat menyurat di lingkungan Kemendikbud, sehingga dapat memudahkan dan cepat dalam penanganan persuratan. SINDE dibuat berdasarkan konsep surat menyurat digital dari platform yang telah tersedia, mengaksesnya dapat menggunakan semacam email ataupun akun yang sudah terdaftar. Aplikasi SINDE telah mengalami banyak pengembangan, baik itu fiturfiturnya maupun pengembangan dari segi aplikasinya, yang dulu hanya berbasis web saja, sekarang dapat diakses melalui aplikasi mobile yang sudah dapat diinstal di smartphone masingmasing penggunanya. Aplikasi SINDE ini hanya dapat digunakan dalam lingkungan Kemendikbud atau bersifat tertutup yang dapat mengakses menggunakan aplikasi ini hanyalah pengguna yang telah terdaftar dari kedinasan, hal tersebut karena untuk membantu kelancaran proses mengelola administrasi persuratan dan disposisinya di setiap satuan kerja di lingkungan Kemendikbud. LPMP yang merupakan Unit Pelaksana Teknis (UPT) pusat di daerah dalam lingkungan Kemendikbud yang mempunyai tugas melaksanakan penjaminan mutu pendidikan 
dasar dan menengah di daerah. LPMP adalah salah satu lembaga yang menggunakan layanan persuratan secara digital dengan menggunakan SINDE. Layanan persuratan ini dapat dilakukan dengan cepat dan tidak terbatas waktu dan tempat. Mengingat tuntutan akan ketersediaan dan aksebilitas terhadap informasi juga makin meningkat. Begitu juga halnya yang diterapkan pada LPMP Provinsi Kalimantan Tengah.

Berdasarkan observasi awal di LPMP Provinsi Kalimantan Tengah pada Sub Bagian Umum dan Kepegawaian secara khusus ada bagian yang mengurusi kegiatan administrasi. Kegiatan tersebut terdiri dari kegiatan persuratan termasuk mengurusi jalannya surat masuk dan surat keluar. Dalam menangani administrasi persuratan ada 3 orang staf yang bertugas untuk menangani kegiatan dari penerimaan, pencatatan, penyimpanan surat. Namun hak untuk mengakses aplikasi SINDE, yaitu: admin, staf, operator surat, pimpinan, dan sekretaris, yang dapat menggunakan aplikasi tersebut. Proses administrasi persuratan pada awalnya masih menggunakan sistem manual. Sistem ini membutuhkan persediaan alat tulis kantor yang cukup banyak, terutama penggunaan kertas, sehingga banyak biaya yang dikeluarkan untuk membeli alat tulis kantor. Sistem manual ini juga membutuhkan waktu dan tenaga dalam proses pendistribusian dokumen. Masalah lainnya dari sistem manual ini adalah sering terjadinya surat yang hilang dikarenakan keterlambatan proses disposisi sehingga menumpuk yang terkadang menyebabkan surat tersebut tercecer, dan juga dalam pencarian dokumen membutuhkan waktu lama. Proses pencarian dimulai dari melihat buku agenda dilanjutkan dengan mencari di rak penyimpanan untuk bisa mendapatkan informasi surat yang dibutuhkan.

Proses secara manual ini dilakukan sampai dengan tahun 2017. Seiring dengan kebutuhan maka pada tahun berikutnya pencatatan agenda surat sudah dilakukan dengan dua cara yaitu dicatat dalam buku agenda dan juga dilakukan pencatatan di dalam aplikasi SINDE. Pada tahun 2018 LPMP Provinsi Kalimantan Tengah mulai mengimplementasikan aplikasi SINDE. Namun pada penerapan penggunaan aplikasi SINDE masih terdapat kendala, yaitu terkait data yang diinput pada SINDE dapat hilang ketika tidak ada aktivitas pada SINDE hal itu disebabkan SINDE dapat logout secara otomatis jika tidak adanya aktifitas selama lebih dari 30 menit. Kendala lainnya juga terdapat pada sumber daya manusia masih ada yang belum bisa menggunakan aplikasi SINDE, belum dapat memahami tata cara penggunaan SINDE, ataupun cara menginput surat pada SINDE. Hal ini dapat dilihat pada aplikasi SINDE yang terdapat penilaian skor aktivitas pengguna yaitu pengukuran keaktifan dalam menginput surat masuk dan pengambilan nomor surat keluar. Dilihat dari penilaian skor aktivitas penggunaan aplikasi SINDE pada LPMP Provinsi Kalimantan Tengah Tahun 2020 tercatat kurang lebih 80\% pengguna yang kurang aktif; sehingga dalam upaya untuk mengatasi hal tersebut perlu dilakukan pengelolan SINDE kepada seluruh pegawai agar dapat memahami dan menggunakan SINDE secara efektif.

Penelitian ini bertujuan untuk mendeskripsikan Manajemen SINDE pada LPMP Provinsi Kalimantan Tenggah.

\section{METODE}

Penelitian ini menggunakan pendekatan kualitatif yang menghasilkan kesimpulan berupa data yang mengambarkan dengan rinci, bukan data yang berupa angka-angka. Menurut Strauss \& Corbin (1990) penelitian kualitatif adalah suatu jenis penelitian yang prosedur penemuan yang dilakukan tidak menggunakan prosedur statistik atau kuantifikasi. Bogdan \& Tylor (dalam Margono, 2009) menyatakan bahwa penelitian kualitatif adalah prosedur penelitian yang menghasilkan data deskriptif berupa kata-kata tertulis dan lisan dari orang-orang yang berprilaku yang dapat diamati. Penelitian ini menggunakan pendekatan kualitatif yang bertujuan menggali fakta kemudian diuraikan sesuai dengan kenyataan yang ada mengenai manajemen SINDE dalam membantu pekerjaan administrasi persuratan dan kearsipan di LPMP Provinsi Kalimantan Tengah. Sumber data dalam penelitian ini yaitu: Kepala Sub Bagian Tata Usaha selaku 
penanggung jawab Staf bidang pengadministrasi umum, Koordinator Persuratan, dan Operator SINDE.

Prosedur pengumpulan data dalam penelitian ini menggunakan metode wawancara, observasi, dan dokumentasi. Analisis data merupakan kegiatan mengubah data hasil penelitian menjadi salah satu informasi yang dapat digunakan untuk mengambil keputusan. Menurut Sugiyono (2010) proses mencari dan menyusun secara sistematis data yang diperoleh dari hasil wawancara, catatan lapangan, dan dokumentasi dengan cara mengorganisasikan data ke kategori, menjabarkan ke dalam unit-unit, melakukan sintesa, menyusun kedalam pola, memilih yang penting dan akan dipelajari, dan membuat kesimpulan sehingga mudah dipahami oleh diri sendiri dan orang lain”. Miles \& Huberman (dalam Margono, 2009) mengatakan analisis data dapat dilakukan dengan menyajikan dua model pokok proses analisis, yaitu: Pertama, model analisis mengalir dimana tiga komponen analisis (reduksi data, sajian data, penarikan kesimpulan/verifikasi) dilakukan saling menjalin dengan proses pengumpulan data dan mengalir bersamaan, dan Kedua model analisis interaksi, dimana komponen reduksi data dan sajian data dilakukan bersamaan dengan proses pengumpulan data. Setelah salah satu terkumpul, maka tiga komponen analisis (reduksi data, sajian data, penarikan kesimpulan) berinteraksi. Analisis data dalam penelitian kualitatif terdiri dari: (1) Pengumpulan data, (2) Reduksi data, (3) Penyajian Data, (4) Penarikan Kesimpulan dan Verifikasi. Uji keabsahan penelitian kualitatif hanya ditekankan pada validitas dan reabilitas, karena dalam penelitian kualitatif tingkat keabsahan lebih ditekankan pada data yang diperoleh. Uji keabsahan data atau kepercayaan terhadap hasil penelitian kualitatif antara lain dilakukan pada perpanjangan pengamatan, peningkatan ketekunan dalam penelitian, triangulasi, diskusi dengan teman sejawat, analisis kasus negatif dan member check. Sugiyono (2010) menyatakan salah satu cara untuk memperolah keabsahan data yaitu dengan meningkatkan kredibilitas data. Ada beberapa cara untuk meningkatkan kredibilitas data terhadap data hasil penelitian kualitatif antara lain: perpanjangan pengamatan, peningkatan ketekunan, triangulasi, diskusi dengan teman sejawat, analisis kasus negatif, dan member chek". Triangulasi adalah pengecekan data dari berbagai sumber dengan berbagai cara, dan berbagai waktu. Triangulasi dalam pengujian kredibilitas ini diartikan sebagai pengecekan data dari berbagai sumber, dengan cara dan berbagai waktu.

\section{HASIL DAN PEMBAHASAN}

\section{Perencanaan Persuratan dan Kearsipan Berbasis SINDE}

Dasar dilakukannya kegiatan perencanaan persuratan dan kearsiapan berbasis SINDE yang dilakukan LPMP adalah menunjang keberhasilan perencanaan yang sudah ditetapkan oleh Kementerian Pendidikan dan Kebudayaan, mulai dari adanya surat edaran yang didapatkan, menyiapkan infastruktur serta fasilitas lainnya yang dibutuhkan, mesosialisasikan terhadap pegawai dibidang administrasi persuratan. Dasar perencanaan kegiataan implementasi ini mengacu pada Peraturan Menteri Pendidikan dan Kebudayaan Republik Indonesia Nomor 2 Tahun 2019 tentang Petunjuk Pelaksanaan Tata Naskah Dinas Elektronik, yang menyebutkan "untuk melaksanakan Tata Naskah Dinas Elektronik Kemeneterian Pendidikan dan Kebudayaan membuat petunjuk pelaksanaan SINDE merupakan acuan yang harus ditetapkan oleh seluruh satuan kerja yang ada di lingkungan Kementerian”. Dalam kegiatan perencanaan ini yang terlibat merupakan pihak yang berperan penting dalam pelaksanaan SINDE di LPMP Provinsi Kalimantan Tengah dengan adanya koordinasi kepada setiap pihak yang terlibat guna mempersiapkan perencanaan yang baik hingga pelaksanaan yang tepat sesuai dengan tujuan yang diharapkan. Pihak yang terlibat dalam perencanaan implementasi SINDE ini, terdiri dari: Kepala LPMP dan Kepala Sub Bagian Tata Usaha sebagai penanggung jawab kegiatan, Pegawai Tata Laksana, Pegawai Pelaksana Standar operasional Prosedur, Pegawai Pengadministrasi Persuratan, serta Koordinator unit pusat Kementerian Pendidikan dan Kebudayaan. Pihak yang terlibat ini mempunyai perannya masing-masing dalam kegiatan perencanaan SINDE. Temuan penelitian ini sejalan dengan pendapat Sawitri (2004) bahwa peranan perencanaan adalah 
sebagai fasilitator untuk menampung pembicaraan yang terjadi dan menjamin bahwa pihak pihak yang ikut serta mendapatkan kesempatan untuk didengar suaranya, konsep ini mengidentifikasi bahwa proses dijalankan dalam konteks tatap muka dengan saling menukar pengetahuan yang dimiliki perencana dengan pendapat pribadi setiap pihak yang ikut serta dalam perencanaan. Handoko (2014) mengungkapkan bahwa di dalam tahap perencanaan terdiri dari: (1) pemilihan atau penetapan tujuan-tujuan organisasi, dan (2) penentuan strategi, kebijaksanaan, proyek, program, prosedur, metode, sistem, anggaran, dan standar, yang dibutuhkan untuk mencapai tujuan. Selain itu, perencanaan diibaratkan sebagai inti manajemen, karena perencanaan membantu untuk mengurangi ketidakpastian di waktu yang akan datang, dan oleh karena itu memungkinkan para pengambil keputusan untuk menggunakan sumberdayasumberdaya mereka yang terbatas secara paling efisien dan efektif.

Sistem kerja yang berkaitan dengan SOP sangat diperhatikan dalam penerapan SINDE dibuat secara detail untuk mengetahui pembagian tugas agar tersedianya aturan yang tersusun dengan tepat. LPMP dalam hal ini telah mengatur susunan standar operasional prosedur agar tersedianya prosedur yang terancang dengan baik dan dapat berjalan sesuai dengan yang sudah ditetapkan dengan melakukan rapat koordinasi menyusun standar operasional prosedur yang memperhatikan persiapan, penilaian kebutuhan SOP, pengembangan SOP, penerapan SOP, serta monitoring dan evaluasi SOP. Hal itu dilakukan agar pelaksanaan kegiatan implementasi mendapat pemahaman tentang pengelolaan SINDE di seluruh unit kerja, terselenggaranya pengelolaan SINDE yang efektif dan efisien. Hal tersebut mengacu pada Peraturan Menteri Pendidikan dan Kebudayaan Nomor 74 Pasal 21 Tahun 2015 tentang Tata Naskah Dinas di Lingkungan Kementerian Pendidikan dan Kebudayaan, yang menyatakan: "Prosedur Operasional Standar administrasi pemerintahan sebagaimana dimaksud dalam pasal 2 ayat (2) huruf c merupakan Naskah Dinas yang memuat serangkaian instruksi tertulis yang dibakukan mengenai berbagai proses penyelenggaraan aktivitas organisasi, bagaimana, dan kapan harus dilakukan, dimana dan oleh siapa dilakukan". LPMP Provinsi Kalimantan Tengah merencanakan sarana dan juga sumber daya untuk mencapai tujuan dan sasaran yang ditetapkan dengan cara memberdayakan pegawai sebaik-baiknya, dan adanya standarisasi sarana dan prasarana seperti hardware, software, maupun infrastruktur jaringan pendukung. Hal ini sesuai dengan Peraturan Menteri Pendidikan dan Kebudayaan Nomor 2 Tahun 2019 tentang Petunjuk Pelaksanaan Tata Naskah Dinas Elektronik bahwa dalam menerapkan sistem pengelolaan Naskah Dinas Elektronik dibutuhkan persyaratan Infrastruktur dan Suprastruktur.

\section{Pengorganisasian Persuratan dan Kearsipan Berbasis SINDE}

Pengorganisasian persuratan dan kearsiapn berbasis SINDE dilakukan dengan penetapan struktur organisasi pengelola SINDE serta pembagian tugas dan tanggung jawab dari masingmasing bagian unit pelaksanaan, diantaranya pengadministrasi persuratan yang berperan dalam penanganan SINDE ini. Pengorganisasian dalam kegiatan ini terdiri dari Kepala LPMP, Kepala Sub Bagian Tata Usaha sebagai penanggung jawab kegiatan, dan kelompok jabatan fungsional yang terfokuskan pada pengadministrasi persuratan ini yang berberan penting dalam pengimplementasian SINDE ini, mengingat SINDE berkaitan dengan urusan persuratan, maka dari itu sejalan dengan pendapat Supriyatna (dalam Arumsari, 2017) menyatakan pada dasarnya pengorganisasian merupakan proses penyusunan struktur organisasi yang sesuai dengan sasaran, sumber daya yang dimiliki, dan lingkungan yang melingkupinya. Pengorganisasian sebagai salah satu fungsi manajemen merupakan sitem kerja sama beberapa orang yang dilaksanakan dengan pembidangan dan pembagian seluruh pekerjaan atau tugas, dengan membentuk sejumlah satuan kerja yang menghimpun pekerjaan dalam satu unit kerja

Tugas dan tanggung jawab penanggung jawab kegiatan implementasi SINDE adalah mengawasi dan mengarahkan setiap pegawai agar melaksanakan tugas dan tanggung jawab dengan baik dan sesuai dengan pedoman pelaksanaan SINDE sehingga pelaksanaan kegiataan ini berjalan dengan baik. Selanjutnya tugas dan tanggung jawab pengadministrasi persuratan 
adalah mengatasi permasalahan persuratan yang sering terjadi sebelum penggunaan SINDE, menerima surat dan menginput surat ke dalam SINDE. Tugas dan tanggung jawab setiap pegawai LPMP aktif dalam mengakses dokumen menggunakan SINDE. Hal ini sesuai dengan pendapat Sedarmayanti (2012) yang menyatakan dalam pengorganisasian keseluruhan proses pengelompokkan tugas yang meliputi fungsi, pengukuran bobot kerja, penetapan wewenang dan tanggung jawab, penempatan orang, penetapan alat hubungan sehingga terbentuk organisasi sebagai suatu kesatuan mekanistik dan siap digerakan untuk mencapai tujuan”. Hal ini juga telah diatur dalam Peraturan Menteri Pendidikan dan Kebudayaan No.2 Tahun 2019 tentang Petunjuk Pelaksanaan Tata Naskah Dinas Elektronik Kementerian Pendidikan Dan Kebudayaan yang menyebutkan pemberian wewenang mengatur kewenangan setiap pengguna, antara lain berupa masukan/input agenda surat, pemindaian dokumen, pembuatan disposisi, dan pembuatan surat keluar. Dalam Sistem Naskah Dinas Elektronik, seorang pengguna dimungkinkan memperoleh beberapa wewenang sekaligus dalam suatu waktu. Kewenangan ini diatur oleh administrator sesuai dengan penugasan yang diberikan.

\section{Pengawasan dan Evaluasi Persuratan dan Kearsipan Berbasis SINDE}

Berdasarkan hasil temuan penelitian diketahui bahwa pengawasan dilakukan oleh penanggung jawab kegiatan dengan memonitoring langsung setiap kegiatan mulai dari perencanaan sampai dengan pelaksanaan kegiatan ini dilakukan terus menerus. Penanggung jawab melakukan pengawsan yang bertujuan untuk mengetahui perkembangan pengguna aplikasi SINDE dengan memantau skor keaktifan setiap pegawai melalui aplikasi SINDE dan juga kegiatan pengawasan dilakukannya pembinaan dalam menilai suatu kegiatan. Pengawasan dan evaluasi dalam implementasi SINDE agar dapat melihat perkembangan dalam pelaksanaan SINDE tersebut dengan mengamati skor evaluasi setiap harinya yang dilakukan oleh penanggung jawab, dalam skor evaluasi akan otomatis terlihat statistik tingkat keaktifan pegawai dalam menggunakan aplikasi SINDE, apabila terdapat pegawai yang mendapat nilai dibawah 60 akan mendapatkan teguran langsung oleh pimpinan, hal itu dilakukan agar mendapatkan bimbingan lebih dan dapat memotivasi pegawai agar dapat lebih aktif lagi. Tujuan dilakukannya pengawasan yaitu untuk mengukur sejauh mana pencapaian dalam kegiatan pelaksanaan yang dilakukan, adapun kegiatan pengawasan juga dilakukannya evaluasi dalam menilai suatu kegiatan. Temuan penelitian ini sejalan dengan pendapat Sedarmayanti (2012) bahwa pengawasan adalah aktivitas tindakan untuk melihat apakah pelaksanaan sesuai dengan perencanaan sebelumnya. Fungsi pengawasan merupakan fungsi terakhir dalam proses manajemen. Keseluruhan fungsi di awal tidak akan berjalan efektif tanpa fungsi pengawasan. Arikunto \& Yuliana (2012) mengatakan pengawasan adalah usaha pimpinan untuk mengetahui semua hal yang menyangkut pelaksanaan kerja, khususnya untuk mengetahui kelancaran kerja para pegawai dalam melakukan tugas mencapai tujuan. Lebih lanjut, Barnawi \& Arifin (2014) mendefinisikan pengawasan sebagai kegiatan untuk menjamin kegiatan-kegiatan atau programprogram telah berjalan sesuai dengan perencanaan untuk mencapai tujuan. Sutisna (1989) mengatakan pengawasan ialah fungsi administratif dalam mana setiap administrator memastikan bahwa apa yang dikerjakan sesuai dengan yang dikehendak. Sementara itu, Kurniadin \& Machali (2014) mengatakan pengawasan dilakukan dalam usaha menjamin bahwa semua kegiatan terlaksana sesuai dengan kebijaksanaan, strategi, keputusan, rencana dan program kerja yang telah dianalisis, dirumuskan, dan ditetapkan sebelumnya. Sedangkan evaluasi dalam persuratan dan kearsipan berbasis SINDE sesuai dengan pendapat Musfah (2012) yang menyatakan evaluasi adalah proses untuk menilai sesuatu baik itu sebuah kegiatan ataupun pencapaian aspek kognitif, keterampilan, dan afektif seseorang atau kelompok, yang bertujuan untuk peningkatan mutu kegiatan atau orang dimasa mendatang. Tujuannya ialah untuk mengetahui secara pasti pencapaian hasil, kemajuan dan kendala yang dijumpai dalam pelaksanaan program/ kegiatan, selanjutnya dipelajari guna perbaikan pelaksanaan program/ kegiatan di masa yang akan datang. Akdon (2006) menyatakan fokus evaluasi kinerja ini 
meliputi: (1) evaluasi masukan (input evaluation), (2) evaluasi proses (process evaluation), (3) evaluasi keluaran (output evaluation), (4) evaluasi hasil (outcome evaluation), serta (5) evaluasi dampak (impact evaluation). Lebih lanjut, dijelaskan bahwa fungsi dari evaluasi adalah untuk mengetahui tingkat keberhasilan dan kegagalan suatu organisasi dan memberikan masukan untuk mengatasi permasalahan yang ada. Keuntungan dari evaluasi bermanfaat untuk perbaikan perencanaan, strategi, kebijakan; untuk pengambilan keputusan; untuk tujuan pengendalian program/ kegiatan; untuk perbaikan input, proses, dan output, perbaikan tatanan atau sistem prosedur.

\section{Faktor Penghambat dalam Manajemen Persuratan dan Kearsipan Berbasis SINDE}

Faktor penghambat dalam manajemen SINDE pada LPMP Provinsi Kalimantan Tengah meliputi: infrastruktur yang kurang memadai, serta sumber daya manusia yang masih sering lalai dalam penggunaan aplikasi SINDE. Kendala infrastruktur disebabkan keterbatasan server yang menyebabkan terjadinya gangguan jaringan saat menggunakan SINDE, disamping faktor gangguan lainnya seperti pemadaman listrik atau cuaca yang kurang baik yang dapat menyebabkan gangguan internet yang membuat terhentinya sistem administrasi persuratan berbasis jaringan internet. Sedangkan kendala terkait sumber daya manusia masih ditemukan kelalaian dalam menjalankan tugasnya serta kurang keaktifannya dalam menggunakan SINDE. Upaya yang dilakukan LPMP Provinsi Kalimantan Tengah untuk mengatasi kendala dalam implementasi SINDE adalah dengan meningkatkan kemampuan SDM melalui pembinaan dan pelatihan, melakukan kerjasama pihak lembaga dengan instansi PLN dan Telkom.

\section{SIMPULAN}

Manajemen SINDE pada Lembaga Penjaminan Mutu Pendidikan (LPMP) Provinsi Kalimantan Tengah sudah berjalan dengan baik, yang dibuktikan dengan: (1) Perencanaan dilakukan dengan dari mengatur susunan SOP, melakukan rapat koordinasi menyusun SOP yang memperhatikan persiapan, penilaian kebutuhan SOP, pengembangan SOP, penerapan SOP, serta Monev SOP; (2) Pengorganisasian dilakukan dengan membentuk struktur organisasi serta tugas dan tanggungjawab personil pengelola SINDE; (3) Pengawasan dan Evaluasi melalui penilaian terhadap pegawai yang aktif dalam menggunakan SINDE; dan (4) Faktor penghambat: keterbatasan jumlah operator SINDE, dan minimnya kecakapan operator SINDE serta kendala teknis lainnya. Upaya untuk mengatasi kendala melalui bimbingan dan pelatihan intensif bagi SDM, serta melakukan kerjasama pihak lembaga dengan instansi PLN dan Telkom.

\section{UCAPAN TERIMA KASIH}

Ucapan terimakasih penulis sampaikan kepada pihak LPMP Provinsi Kalimantan Tengah yang telah memberikan izin dan kemudahan proses selama berlangsungnya kegiatan penelitian, serta Redaksi Equity in Education Journal (EEJ) yang telah memberikan kesempatan artikel penulis dapat dimuat dalam jurnal ini.

\section{DAFTAR PUSTAKA}

Akdon. (2006). Strategic Management for Educational Management (Manajemen Strategik untuk Manajemen Pendidikan). Bandung: Alfabeta.

Arikunto, S., \& Yuliana, L. (2012). Manajemen Pendidikan. Yogyakarta: Aditya Media Yogyakarta.

Arumsari, N. R. (2017). Penerapan Planning, Organizing, Actuating, dan Controlling di UPTD DIKPORA Kecamatan Jepara. Jurnal Ekonomi dan Bisnis Kontemporer, 3(2).

Barnaw., \& Arifin, M. (2014). Manajemen Sarana \& Prasarana Sekolah. Jogjakarta: AR-RUZZ MEDIA.

Handoko, T. H. (2014). Manajemen (Edisi 2). Yogyakarta: BPFE-Yogyakarta. 
162 Equity in Education Journal (EEJ), Vol. 3, No. 2, Oktober 2021

Kurniadin, D., \& Machali, I. (2014). Manajemen Pendidikan Konsep \& Prinsip Pengelolaan Pendidikan. Jogjakarta: AR-RUZZ MEDIA.

Margono, S. (2009). Metodologi Penelitian Kualitatif. Bandung: Citapustaka Media.

Margono. (2009). Kumpulan Pendapat menurut Para Ahli. Diterima dari https://www.cryptowi.com/pengertian-penelitian/.

Musfah, J. (2012). Peningkatan Kompetensi Guru Melalui Pelatihan dan Sumber Belajar Teori dan Praktik. Jakarta: Kencana Prenada Media Group.

Peraturan Menteri Pendayagunaan Aparatur Negara dan Reformasi Birokrasi (Permenegpan-RB) Nomor 5 Tahun 2017 tentang Pedoman Tata Naskah Dinas Di Lingkungan Kementerian Pendayagunaan Aparatur Negara dan Reformasi Birokrasi Republik Indonesia.

Peraturan Menteri Pendayagunaan Aparatur Negara dan Reformasi Birokrasi (Permengpan-RB) Nomor 6 Tahun 2011 tentang Pedoman Umum Tata Naskah Dinas Elektronik.

Peraturan Menteri Pendidikan dan Kebudayaan (Permendikbu) Nomor 2 Tahun 2019 tentang Petunjuk Pelaksanaan Tata Naskah Dinas Elektronik Kementerian Pendidikan dan Kebudayaan.

Peraturan Menteri Pendidikan dan Kebudayaan (Permendikbud) Nomor 74 Tahun 2015 tentang Tata naskah dinas di Lingkungan Kementerian Pendidikan dan Kebudayaan.

Sawitri, D. (2006). Profesi Perencana dalam Perencanaan Partisipatif Suatu Kajian Teori dan Praktek Perencanaan. Vol 22 (No.1):22

Sedarmayanti. (2012). Manajemen dan Komponen Terkait Lainnya. Bandung: Refika Aditama

Strauss, A., \& Corbin, J. (1990). Metodologi Penelitian Kualitatif. (Cetakan ke-5). BandungL Citapustaka Media.

Sugiyono. (2010). Metode Penelitian Kuantitatif Kualitatif dan R\&D. Alfabet, Bandung

Sutisna, O. (1989). Administrasi Pendidikan Dasar Teoritis untuk Praktek Profesional. Bandung: ANGKASA. 